\title{
Teaching Old Dogs New Tricks Or Simply Using The Old Tricks At The Right Time
}

Ken Henderson, (E-mail: k.henderson@moreheadstate.edu), Morehead State University Shane Spiller, (E-mail: s.spiller@moreheadstate.edu), Morehead State University Michelle Kunz, (E-mail: m.kunz@moreheadstate.edu), Morehead State University Janet Ratliff, (E-mail: j.ratliff@ moreheadstate.edu), Morehead State University

\begin{abstract}
This study used a specially designed questionnaire to explore student perceptions of tertiary service quality and preferences for fourteen commonly used teaching methods within five dimensions of higher learning. A convenience sample of 243 undergraduate and graduate students was drawn. Overall, the similarities in the service quality gap between these student groups were greater than the differences. Specifically, students perceived their education emphasized learning of facts and principles but they preferred to be taught learning of skills and procedures. Their most favored learning methods were textbooks and lectures and their least favored learning methods were role playing and team presentations. The perceived comparative value of the effectiveness of alternative teaching tools in accomplishing five dimensions of higher learning is discussed.
\end{abstract}

\section{Introduction}

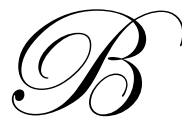

usiness academicians face a conundrum, namely guarding against unintentional teaching myopia while tertiary education undergoes substantial changes toward creating a student-centered environment. Teaching myopia occurs when educators focus on teaching rather than the needs of learners (Cunningham 1996). The American Assembly of Collegiate Schools of Business, universities, schools, and departments increasingly emphasize matching teaching styles with learning styles (American Assembly of Collegiate Schools of Business Task Force on Effective and Inclusive Learning Environments 1998). Potential conflict arises because research suggests academicians tend to use teaching techniques that fit into their own preferred learning styles (Campbell 1990) and are related to their personal comfort with specific teaching procedures and course content (Grasha 1990). The conundrum is exacerbated because student evaluations of teaching are one method widely used by many colleges to measure positive, effective learning environments. Since the opinions expressed by students may affect the longevity and success of academicians' careers (Watters 2000), educators need to understand how students evaluate various teaching methods. Knowledge of these preferences could allow professors to better match their teaching methods with learning styles and anticipate student evaluations.

In recent years the focus of pedagogical research has shifted from teacher performance to learner response (Cross and Steadman 1996). However, despite a growing body of literature examining learner needs, motivation, and skills (Cook 1997; Cross and Steadman 1996; Mclean 2001; Sander, Stevenson, King, and Coates 2000; Wright 1996), little research has been conducted with regard to student preferences among the multitude of teaching methods. This study pursues this topic by measuring how undergraduate and graduate students perceive the effectiveness of alternative learning tools within five key dimensions of their higher learning. Specifically, this paper examines the perceived comparative value of the effectiveness of alternative teaching tools in accomplishing five dimensions of higher learning. Armed with this knowledge, academicians can begin to unravel the teaching conundrum when they incorporate students' learning style preferences into their lesson planning.

Readers with comments or questions are encouraged to contact the authors via email. 


\section{Service Quality and Expectations of Higher Education}

Higher education possesses all the characteristics of a service industry. Educational services are intangible and cannot be evaluated fully by prospective students. Educational services also are inseparable from the professors delivering it with their heterogeneous teaching styles to students who simultaneously participate in the process. Service is a feature that differentiates many universities (DiDomenico and Bonnici 1996) and perceptions of service quality are a main predictor of student satisfaction.

During the past decade, conceptualization of service quality has received considerable attention (Babakus and Boiler 1992; Bateson 1992; Bolton and Drew 1991; Cronin and Taylor 1994; Mano and Oliver 1993; Oliver 1993; Parasuraman, Berry and Zeithaml 1993; Teas 1993; Zeithaml, Berry and Parasuraman 1993). This research suggests that service quality concerns the perceived evaluation of whether service delivery meets, exceeds or falls short of customer expectations. Parasuraman, Zeithaml and Berry (1988) define expectations as "desires or wants of customers." In higher education, service quality is determined from the perspective of students who calculate whether their actual learning experience exceeds or meets their expectations (i.e. satisfaction) or falls short of their expectations (i.e. dissatisfaction). Herein lays the conundrum. Students, not educators assuming they know what students want, set the standards by which service quality is measured. Unsatisfied students may impart negative comments on teaching evaluations or transfer to other institutions (DiDomenico and Bonnici 1996). Both outcomes have deleterious results for faculty and universities.

\section{Service Quality Gaps and Learning Dimensions}

Recent research has applied gap analysis in academic settings (Hampton 1993). DiDomenico and Bonnici (1996) recommend measuring both student expectations and perceptions in order to expose expected versus perceived quality gaps. This paper argues measuring service quality is a prerequisite for devising teaching plans and skillfully using teaching tools that deliver satisfying learning experiences. However, we do not imply that student expectations and preferences should automatically drive curriculum or teaching methods. Rather gap analysis can identify areas where modified pedagogical emphasis and the use of alternative teaching tools can engage students in rigorous ways of learning which students prefer.

This study measures student perceptions of service quality along five hierarchical dimensions of higher learning proposed by Angelo (1993). These dimensions are Declarative Learning (learning of facts and principles), Procedural Learning (learning of skills and procedures), Conditional Learning (learning of applications), Reflective Learning (learning to understand one's self), and Metacognitive Learning (learning to manage one's learning)

\section{Research Method}

\subsection{Subjects}

Subjects were 243 students (51\% male and $49 \%$ female) drawn from six undergraduate and three graduate subjects taught in the College of Business of a major university in Kentucky. The total sample was composed of 72 (29.6\%) freshmen and sophomores, 86 (35.4\%) juniors and seniors, and $85(35.0 \%)$ MBA students. The majority $(81.6 \%)$ were less than 30 years old although nearly one-third (32\%) possessed at least 5 years of employment experience. Course instructors administered the questionnaires. Participation in the study was voluntary.

\subsection{Instrument}

The Learning Preferences Questionnaire measures students' perceptions of the gaps between actual and preferred learning emphasis that occurs in five dimensions of higher learning. The questionnaire has four sections. Students quantify the percentage of learning emphasis that actually occurs in their degree program along learning principles and facts, skill and procedures, applications, understanding self, and managing personal learning dimensions (totalling 100\%). They repeat the process reporting preferred percentages of emphasis (totalling 100\%). The perceptual gaps are calculated as the differences between the actual and preferred percentiles. Next, students eva- 
luate the effectiveness of fourteen alternative learning tools to promote higher learning in each of these dimensions using a 3-point scale (very effective, neither effective nor ineffective, very ineffective). The fourteen learning tools are lectures, textbooks, supplemental reading materials, small group sessions with fellow students, one-on-one meetings with teacher, case studies (three or more pages read prior to class), case scenarios (less than three pages read during class meeting), tutorials, videos and other electronic materials, guest speakers, research papers, internet activities, team presentations, and role playing. Students also ranked these learning tools based on their personal preferences. Basic demographic information also is collected.

\section{Results}

Overall means and standard deviations on the tests of the five higher learning dimensions are presented in Table 1. Although t-tests reveal an overall significant difference (d.f. $=236, p=.046$ ) between the learning emphasis actually occurring in the degree program and the emphasis preferred by students, only three of the five dimensions show significant differences between teaching and learning preferences. Students report that they receive more declarative learning emphasis $(p<.001)$ and less procedural $(p<.001)$ and reflective learning emphasis $(p=$ $.004)$ than they prefer.

\begin{tabular}{|c|c|c|c|c|c|c|c|c|}
\hline \multirow{2}{*}{$\begin{array}{l}\text { Dimension of Higher Learning } \\
\text { Actual Declarative Learning }\end{array}$} & \multicolumn{2}{|c|}{$\begin{array}{c}\text { Students } \\
\text { Years 1-2 }\end{array}$} & \multicolumn{2}{|c|}{$\begin{array}{l}\text { Students } \\
\text { Years 3-4 }\end{array}$} & \multicolumn{2}{|c|}{$\begin{array}{c}\text { MBA } \\
\text { Students }\end{array}$} & \multicolumn{2}{|c|}{ Total } \\
\hline & 31.71 & 17.34 & 34.49 & 17.35 & 31.16 & 15.89 & 32.66 & 16.81 \\
\hline Preferred Declarative Learning & 25.67 & 15.87 & 26.55 & 15.11 & 25.06 & 11.81 & 25.91 & 14.26 \\
\hline Actual Procedural Learning & 21.50 & 11.34 & 22.19 & 11.58 & 22.35 & 7.58 & 22.12 & 10.25 \\
\hline Preferred Procedural Learning & 25.89 & 12.20 & 26.80 & 13.99 & 26.96 & 12.83 & 26.59 & 12.95 \\
\hline Actual Conditional Learning & 19.06 & 9.58 & 18.53 & 11.96 & 20.64 & 10.64 & 19.43 & 10.81 \\
\hline Preferred Conditional Learning & 19.34 & 10.97 & 19.24 & 12.30 & 21.63 & 11.52 & 20.17 & 11.61 \\
\hline Actual Reflective Learning & 14.19 & 8.70 & 13.83 & 10.73 & 13.25 & 8.00 & 13.72 & 9.26 \\
\hline Preferred Reflective Learning & 15.56 & 10.19 & 16.15 & 11.88 & 15.08 & 10.79 & 15.55 & 10.97 \\
\hline Actual Metacognitive Learning & 12.59 & 7.95 & 13.09 & 10.65 & 14.98 & 10.12 & 13.47 & 9.78 \\
\hline Preferred Metacognitive Learning & 13.26 & 8.93 & 14.87 & 11.04 & 15.71 & 11.65 & 14.60 & 10.66 \\
\hline
\end{tabular}

Table 2 Students' Evaluations of Alternative Learning Tools

\begin{tabular}{|l|c|c|c|c|}
\hline Learning Tool & $\begin{array}{c}(\mathbf{1}) \\
\text { Very Effective }\end{array}$ & $\begin{array}{c}\mathbf{2}) \\
\text { Very Ineffective }\end{array}$ & $\begin{array}{c}(\mathbf{3}) \\
\text { Neither Effective } \\
\text { Nor Ineffective }\end{array}$ & $\begin{array}{c}\text { Overall } \\
(\mathbf{1 - 2})\end{array}$ \\
\hline One-on-one & 67.02 & 6.00 & 26.98 & 61.02 \\
\hline Cases & 38.86 & 12.84 & 48.3 & 26.02 \\
\hline Group sessions & 61.18 & 8.6 & 30.26 & 52.58 \\
\hline Guest speaker & 34.91 & 17.33 & 47.76 & 17.57 \\
\hline Lecture & $51.8 \%$ & $13.7 \%$ & $34.5 \%$ & $38.1 \%$ \\
\hline Supplemental Reading & 45.89 & 14.11 & 40.00 & 31.78 \\
\hline Role playing & 44.77 & 15.95 & 39.29 & 28.82 \\
\hline Scenarios & 43.39 & 11.97 & 44.64 & 31.42 \\
\hline Internet Activities & 50.04 & 10.95 & 39.00 & 39.09 \\
\hline Textbooks & 48.96 & 17.04 & 34.00 & 18.96 \\
\hline Tutorials & 43.76 & 10.23 & 46.01 & 33.53 \\
\hline Electronic materials & 49.09 & 9.55 & 41.36 & 39.54 \\
\hline Research papers & 41.15 & 20.78 & 38.07 & 20.37 \\
\hline Team Presentations & 50.46 & 13.53 & 36.02 & 36.93 \\
\hline
\end{tabular}


Table 2 summarizes the overall effective scores of the learning alternative tools. Students ranked one-onone meetings with instructors as the aggregate most effective learning tool (very effective minus very ineffective $=$ $61 \%$ effective rating) across the five dimensions. Guest speakers (17.57\% effective rating) was judged to be the least effective.

Table 3 presents the effective scores across the three measures of student groups. No significant effectiveness differences were found. favorite).

Table 4 lists the rank order of learning tools in terms of student preference $(1=$ most favorite, $12=$ least

\begin{tabular}{|c|c|c|c|c|}
\hline Learning Tool & $\begin{array}{c}\text { Overall } \\
\text { Effectiveness }\end{array}$ & $\begin{array}{l}\text { Students } \\
\text { Years 1-2 }\end{array}$ & $\begin{array}{l}\text { Students } \\
\text { Years 3-4 }\end{array}$ & $\begin{array}{c}\text { MBA } \\
\text { Students }\end{array}$ \\
\hline One-on-one & $61.02(1)$ & $66.39(1)$ & $67.06(1)$ & $49.76(4)$ \\
\hline Cases & $26.02(11)$ & $10.02(14)$ & $15.17(13)$ & $50.96(3)$ \\
\hline Group sessions & $52.58(2)$ & $48.88(2)$ & $57.86(2)$ & $51.08(2)$ \\
\hline Guest speaker & $17.57(14)$ & $22.90(10)$ & $19.39(12)$ & $10.84(14)$ \\
\hline Lecture & $38.10(1)$ & $37.71(5)$ & $41.71(5)$ & $31.33(12)$ \\
\hline Supplemental Reading & $31.78(8)$ & $25.49(9)$ & $20.15(11)$ & $49.28(5)$ \\
\hline Role playing & $28.82(10)$ & $30.66(7)$ & $35.16(7)$ & $20.05(13)$ \\
\hline Scenarios & $31.42(9)$ & $21.0(11)$ & $25.89(9)$ & $46.51(6)$ \\
\hline Internet Activities & $39.09(4)$ & $26.74(8)$ & $46.32(3)$ & $42.89(7)$ \\
\hline Textbooks & $18.96(13)$ & $19.89(12)$ & $20.38(10)$ & $53.14(1)$ \\
\hline Tutorials & $33.53(7)$ & $33.62(6)$ & $31.28(8)$ & $36.32(9)$ \\
\hline Electronic materials & $39.54(3)$ & $42.61(3)$ & $45.02(4)$ & $32.20(11)$ \\
\hline Research papers & $20.37(12)$ & $10.64(13)$ & $10.94(14)$ & $37.59(8)$ \\
\hline Team Presentations & $36.93(6)$ & $41.79(4)$ & $37.05(6)$ & $32.78(10)$ \\
\hline
\end{tabular}

Table 4 Students' Rank Order Preferences for Learning Tools

\begin{tabular}{|l|c|c|c|c|}
\hline Learning Tool & $\begin{array}{c}\text { Table 4 Students' Rank Order Preferences for Learning Tools } \\
\text { Overall } \\
\text { Preference Rank- } \\
\text { ing }\end{array}$ & $\begin{array}{c}\text { Students } \\
\text { Years 1-2 } \\
\text { Mean / Rank } \\
\text { Mean / Rank }\end{array}$ & $\begin{array}{c}\text { Students } \\
\text { Years 3-4 } \\
\text { Mean / Rank }\end{array}$ & $\begin{array}{c}\text { MBA } \\
\text { Students } \\
\text { Mean / Rank }\end{array}$ \\
\hline One-on-one & $6.39 / 4$ & $4.91 / 1$ & $6.08 / 3$ & $7.36 / 8$ \\
\hline Cases & $7.61 / 8$ & $8.28 / 11$ & $8.52 / 13$ & $6.00 / 3$ \\
\hline Group sessions & $5.51 / 2$ & $5.78 / 4$ & $5.11 / 2$ & $6.00 / 3$ \\
\hline Guest speaker & $7.86 / 10$ & $7.44 / 8$ & $7.02 / 7$ & $9.25 / 12$ \\
\hline Lecture & $4.82 / 1$ & $5.47 / 3$ & $4.52 / 1$ & $4.96 / 2$ \\
\hline Supplemental Reading & $7.45 / 7$ & $7.94 / 9$ & $7.85 / 9$ & $6.62 / 5$ \\
\hline Role playing & $8.73 / 13$ & $7.33 / 7$ & $8.08 / 10$ & $10.27 / 14$ \\
\hline Scenarios & $7.76 / 9$ & $8.69 / 13$ & $8.08 / 10$ & $6.92 / 6$ \\
\hline Internet Activities & $7.01 / 5$ & $6.94 / 5$ & $6.97 / 5$ & $7.16 / 7$ \\
\hline Textbooks & $6.00 / 3$ & $7.09 / 6$ & $6.98 / 6$ & $4.07 / 1$ \\
\hline Tutorials & $8.38 / 11$ & $8.53 / 12$ & $8.20 / 12$ & $8.60 / 10$ \\
\hline Electronic materials & $7.13 / 6$ & $5.40 / 2$ & $6.52 / 4$ & $8.73 / 11$ \\
\hline Research papers & $9.29 / 14$ & $9.70 / 14$ & $9.77 / 14$ & $8.47 / 9$ \\
\hline Team Presentations & $8.49 / 12$ & $8.03 / 10$ & $7.81 / 8$ & $9.71 / 13$ \\
\hline
\end{tabular}




\section{Discussion}

Service quality is growing increasingly important as colleges and universities become more studentoriented. Research suggests that customers evaluate service quality in terms of whether their desires have been met (Spreng, MacKenzie, and Olshavsky 1996). Higher education uses student evaluations of teaching performance to monitor and understand student expectations. This practice is dangerous when educators emphasize dimensions of learning that differ from the dimensions students prefer.

This study identifies an important dimension of higher education - the gap between what educators focus on and the dimensions of higher learning that learners prefer. The results of this study suggest that tertiary institutions may be unintentionally exacerbating the performance evaluation conundrum by delivering dimensions of learning that are inconsistent with the learning preferences of students. As a result, students may grow dissatisfied with the learning experience and vent their frustration in poor teaching evaluations.

\section{References}

1. American Assembly of Collegiate Schools of Business Task Force on Effective and Inclusive Learning Environments (1998) Effective and inclusive learning environments. International Association for Management Education.

2. Angelo, T.A., “A Teacher's Dozen: Fourteen General, Research-based Principles for Improving Higher Learning in Our Classrooms," The AAHE Bulletin, 45 (8), April 1993, pp. 3-7 \& 13.

3. Babakus, Emin and Gregory E. Boiler, 1992. "An Empirical Assessment of the SERVQUAL Scale." Journal of Business Research, 24, 253-268.

4. Bateson, J.E.G., 1992. Managing Services Marketing. Fort Worth, TX: Dryden Press. 493-520. Bolton, Ruth N. and James H. Drew, 1991. "A Multistage Model of Customer Assessments of Service Quality and Value." Journal of Consumer Research, 375-384.

5. Campbell, B.J. (1991) Planning For A Student Learning Style, Journal of Education for Business, Jul/Aug, $66,6$.

6. Cook, Michael J. (1997) A Student's Perspective Of Service Quality In Education, Total Quality Management. 8, 2/3, 120.

7. Cronin, J. Joseph, Jr. and Steven A Taylor, 1994. "SERVPERF versus SERVQUAL: Reconciling Performance-Based and Perceptions-Minus-Expectations Measurement of Service Quality." Journal of Consumer Research, 375-384.

8. Cross, K. Patricia and M. Steadman. Classroom Research: Implementing the Scholarship of Teaching. Jossey-Bass, Inc., San Francisco, CA 1996, p.2.

9. Cunningham, A.C. (1996), "Marketing teachers beware the trap of pedagogy!" Proceedings of the 1996 Australian Marketing Educators' Conference, Marketing Science Centre, University of South Australia.

10. DiDomenico, Edith and Joseph Bonnici (1996) Assessing Service Quality Within The Educational Environment. Education, 116, 3, 353-360.

11. Grasha, A. F. (1990). Using traditional versus naturalistic approaches to assessing learning styles in college teaching. Journal on Excellence in College Teaching, 1, 23-38.

12. Hampton, G. (1993). Gap Analysis of College Student Satisfaction as a Measure of Professional Service Quality. Journal of Professional Services Marketing, 9(1), 115-128.

13. Mano, Haim and Richard L. Oliver, 1993. "Assessing the Dimensionality and Structure of the Consumption Experience: Evaluation, Feeling, and Satisfaction." Journal of Consumer Research, 20 (December). Nunnaly, J.C., 1967. Psychometric Methods. New York: McGraw-Hill Book Company.

14. Mclean, Michelle (2001) Can We Relate Conceptions Of Learning To Student Academic Achievement? Teaching in Higher Education, 6, 3, 399-414.

15. Oliver, Richard L., 1993a. "A Conceptual Model of Service Quality and Service Satisfaction: Compatible Goals, Different Concepts." Advances in Services Marketing and Management, Vol. 2, Teresa A. Swartz, David E. Bowen, and Stephen W. Brown (eds.). Greenwich, CT: JAI Press, 65-85.

16. Parasuraman, A., Leonard L. Berry and Valarie Zeithaml, 1993. "More on Improving Service Quality Measurement." Journal of Retailing, 69: 1: 140-147. 
17. Parasuraman, A., Valarie Zeithaml, and Leonard Berry, 1988. "SERVQUAL: A Multiple-Item Scale for Measuring Consumer Perceptions of Service Quality." Journal of Retailing, 64 (spring): 12-40.

18. Sander, Paul, Keith Stevenson, Malcolm King, and David Coates (2000) University Students' Expectations Of Teaching. Studies in Higher Education, 25, 3, 309-324.

19. Spreng, Richard A., Scott B. MacKenzie, and Richard W. Olshavsky (1996), "A Reexamination of the Determinants of Consumer Satisfaction," Journal of Marketing, 60 (July), 15-32.

20. Teas, R. Kenneth,1993. "Consumer Expectations and the Measurement of Perceived Service Quality." Journal of Professional Services Marketing, 8: 2: 33-54.

21. Watters, Mike (2000) Reciprocal Questioning And Computer-Based Instruction In Introductory Auditing: Student Perceptions, Journal of Education for Business, May/Jun, 75, 5.

22. Wright, Robert E. (1996) Quality Factors In Higher Education: The Students' Viewpoint College Student Journal, 30, 2, 269.

23. Zeithaml, Valarie A., Leonard L. Berry, and A. Parasuraman, 1993. "The Nature and Determinants of Customer Expectations of Service." Journal of the Academy of Marketing Science, 21 (winter): 1-12. 